\title{
Cytotoxicity and genotoxicity of low doses of mercury chloride and methylmercury chloride on human lymphocytes in vitro
}

L.C. Silva-Pereira ${ }^{1,2}$, P.C.S. Cardoso ${ }^{2,4}$, D.S. Leite ${ }^{2}$, M.O. Bahia ${ }^{3,4}$, W.R. Bastos ${ }^{5}$, M.A.C. Smith ${ }^{6}$ and R.R. Burbano ${ }^{2,6}$
1Departamento de Pós-Graduação, Faculdade de Itaituba, Itaituba, PA, Brasil ${ }^{2}$ Departamento de Biologia, ${ }^{3}$ Departamento de Patologia, Centro de Ciências Biológicas, Universidade Federal do Pará, Belém, PA, Brasil

${ }^{4}$ Departamento de Genética, Faculdade de Medicina de Ribeirão Preto, Universidade de São Paulo, Ribeirão Preto, SP, Brasil

${ }^{5}$ Laboratório de Biogeoquímica Ambiental, Departamento de Medicina, Fundação Universidade Federal de Rondônia, Porto Velho, RO, Brasil ${ }^{6}$ Disciplina de Genética, Departamento de Morfologia, Escola Paulista de Medicina, Universidade Federal de São Paulo, São Paulo, SP, Brasil

\section{Correspondence}

R.R. Burbano

Disciplina de Genética

Departamento de Morfologia, UNIFESP

Rua Botucatu, 740

04023-900 São Paulo, SP

Brasil

Fax: +55-11-5576-4260/5576-4264

E-mail: rommel@ufpa.br

Research supported by CAPES (No. 016/2000-CAPES-FADESP,

Sub-Projeto No. 21).

L.C. Silva-Pereira was supported by a

CAPES scholarship.

Publication supported by FAPESP.

$\ldots \ldots \ldots \ldots \ldots \ldots \ldots \ldots$

Received January 30, 2004 Accepted March 2, 2005

\begin{abstract}
Mercury is a xenobiotic metal that is a highly deleterious environmental pollutant. The biotransformation of mercury chloride $\left(\mathrm{HgCl}_{2}\right)$ into methylmercury chloride $\left(\mathrm{CH}_{3} \mathrm{HgCl}\right)$ in aquatic environments is well-known and humans are exposed by consumption of contaminated fish, shellfish and algae. The objective of the present study was to determine the changes induced in vitro by two mercury compounds $\left(\mathrm{HgCl}_{2}\right.$ and $\left.\mathrm{CH}_{3} \mathrm{HgCl}\right)$ in cultured human lymphocytes. Short-term human leukocyte cultures from 10 healthy donors (5 females and 5 males) were set-up by adding drops of whole blood in complete medium. Cultures were separately and simultaneously treated with low doses ( 0.1 to $1000 \mu \mathrm{g} / \mathrm{l})$ of $\mathrm{HgCl}_{2}$ and $\mathrm{CH}_{3} \mathrm{HgCl}$ and incubated at $37^{\circ} \mathrm{C}$ for $48 \mathrm{~h}$. Genotoxicity was assessed by chromosome aberrations and polyploid cells. Mitotic index was used as a measure of cytotoxicity. A significant increase $(\mathrm{P}<0.05)$ in the relative frequency of chromosome aberrations was observed for all concentrations of $\mathrm{CH}_{3} \mathrm{HgCl}$ when compared to control, whether alone or in an evident sinergistic combination with $\mathrm{HgCl}_{2}$. The frequency of polyploid cells was also significantly increased $(\mathrm{P}<$ 0.05 ) when compared to control after exposure to all concentrations of $\mathrm{CH}_{3} \mathrm{HgCl}$ alone or in combination with $\mathrm{HgCl}_{2} . \mathrm{CH}_{3} \mathrm{HgCl}$ significantly decreased $(\mathrm{P}<0.05)$ the mitotic index at 100 and 1000 $\mu \mathrm{g} / \mathrm{l}$ alone, and at $1,10,100$, and $1000 \mu \mathrm{g} / 1$ when combined with $\mathrm{HgCl}_{2}$, showing a synergistic cytotoxic effect. Our data showed that low concentrations of $\mathrm{CH}_{3} \mathrm{HgCl}$ might be cytotoxic/genotoxic. Such effects may indicate early cellular changes with possible biological consequences and should be considered in the preliminary evaluation of the risks of populations exposed in vivo to low doses of mercury.
\end{abstract}

Key words

- Methylmercury

- Cytotoxicity

- Genotoxicity

- Mitotic index

- Human lymphocytes

- Chromosome aberrations 


\section{Introduction}

Mercury, one of the most widely diffused and hazardous organ-specific environmental contaminants, exists in a wide variety of physical and chemical states, each of which with unique characteristics of target organ specificity (1). In nature, the different forms of mercury include the metallic form, inorganic compounds as well as alkyl, alkoxy and aryl mercury compounds. Once introduced into the environment, mercury compounds can undergo a wide variety of transformations. In sediments, inorganic mercury $\left(\mathrm{HgCl}_{2}\right)$ may be converted into methyl $\left(\mathrm{CH}_{3} \mathrm{HgCl}\right)$ and dimethyl $\left(\mathrm{CH}_{3} \mathrm{CH}_{2} \mathrm{HgCl}\right)$ forms by methanogenic bacteria. This biotransformation constitutes a serious environmental risk, given that $\mathrm{CH}_{3} \mathrm{HgCl}$ is the most toxic of the mercury compounds and accumulates in the aquatic food chain, eventually reaching human diets (2). $\mathrm{CH}_{3} \mathrm{HgCl}$ has been an environmental concern to public health and regulatory agencies for over 50 years because of its neurotoxicity. Its association with nervous system toxicity in adults and infants near Minamata Bay, Japan, in the 1950's initiated environmental health research inquiries that continue to this day (3). The three modern "faces" of mercury are our perceptions of risk from the exposure of billions of people to $\mathrm{CH}_{3} \mathrm{HgCl}$ in fish, mercury vapor from amalgam tooth fillings and $\mathrm{CH}_{3} \mathrm{CH}_{2} \mathrm{HgCl}$ in the form of thimerosal added as an antiseptic to widely used vaccines (4).

Mercury genotoxicity has been usually attributed to its ability to react with the sulfhydryl groups of tubulin, impairing spindle function and leading to chromosomal aberrations and polyploidy (5). Another important mechanism of mercury genotoxicity is its ability to produce free radicals that can cause DNA damage $(6,7)$. In vivo studies have demonstrated a clastogenic effect of mercury on people exposed to this element in their work environment, through the consumption of contaminated food, or acciden- tally. Increased numbers of chromosome alterations and micronuclei have been reported in people who consume contaminated fish $(8,9)$ and in miners and workers of explosive factories $(10,11)$. Negative results were also obtained in some cases $(12,13)$, demonstrating that cytogenetic monitoring of peripheral blood lymphocytes in individuals exposed to mercury from different sources may not be completely specific (5).

The effects of $\mathrm{CH}_{3} \mathrm{HgCl}$ contamination have been studied in an increasing way since the outbreaks in Japan and Iraq. Many of these studies had its focus on the neurological effects of $\mathrm{CH}_{3} \mathrm{HgCl}$ exposure in adult animals and used high doses of this compound (1900 to $30,000 \mathrm{ppb}=\mu \mathrm{g} / \mathrm{l})$ to obtain its most severe effects (14). Most of the in vitro studies with lymphocytes also used high doses $(250$ to $6250 \mu \mathrm{g} / \mathrm{l})$ of mercury compounds in order to evaluate its clastogenic effects (15-17).

In the present study, we determined the changes induced in human lymphocyte cultures in vitro by two mercury compounds, inorganic $\mathrm{HgCl}_{2}$ and organic $\mathrm{CH}_{3} \mathrm{HgCl}$. Low doses were used in order to assess the genotoxic and cytotoxic effects of these compounds at concentrations normally found in nature (40 to $500 \mu \mathrm{g} / 1$ in the earth's crust environment) (2). Furthermore, we intended to obtain additional information which could be used in a preliminary evaluation of the risks to populations exposed in vivo.

\section{Material and Methods}

\section{Chemical agents}

$\mathrm{HgCl}_{2}$ and $\mathrm{CH}_{3} \mathrm{HgCl}$ were purchased from Ultra Scientific ${ }^{\circledR}$ (North Kingstown, RI, USA). Distilled water and ethanol (Sigma, St. Louis, $\mathrm{MO}$, USA) were used to dilute $\mathrm{HgCl}_{2}$ and $\mathrm{CH}_{3} \mathrm{HgCl}$, respectively. Ten microliters of each agent were added either separately or together to a 5-ml aliquot of a cell suspension in order to obtain final concentrations of 0.1 , 
$1,10,100$, and $1000 \mu \mathrm{g} / 1$ for each of the agents used for the cytogenetic tests. Cells treated only with vehicles (distilled water or ethanol) were used as controls. The concentration range used in the present study ( 0.1 to $1000 \mu \mathrm{g} / \mathrm{l})$ corresponded to levels observed normally in nature (low doses) (2).

\section{In vitro test with human peripheral blood lymphocytes}

Blood samples were obtained from 10 healthy nonsmokers, 5 females and 5 males, aged 18-30 years, with no recent history of exposure to mutagens. The donors gave informed written consent to participate in the study. Cultures were prepared with $1 \mathrm{ml}$ plasma in 5-ml culture medium consisting of 80\% RPMI-1640 medium (Gibco, Paisley, UK), 20\% fetal calf serum (Cultilab, Campinas, SP, Brazil) with antibiotics (100 IU penicillin $/ \mathrm{ml}$ and $100 \mu \mathrm{l}$ streptomycin $/ \mathrm{ml}$, Gibco) and $4 \%$ phytohemagglutinin (Cultilab). The previously cited concentrations were added to each culture $9 \mathrm{~h}$ after the beginning of incubation. For cytogenetic analysis, the lymphocyte cultures were incubated in a water-bath at $37^{\circ} \mathrm{C}$ for $48 \mathrm{~h}$. Colchicine $(0.8$ $\mathrm{mM}$; Sigma) was added to the cultures $2 \mathrm{~h}$ before harvest to obtain a maximum number of cells at metaphase.

Cells were harvested by centrifugation $(300 \mathrm{~g})$, treated for $10 \mathrm{~min}$ with $0.075 \mathrm{M} \mathrm{KCl}$ (Merck, Darmstadt, Germany), and fixed with 1:3 Carnoy fixative (glacial acetic acid:absolute methanol). Slides were prepared, air-dried and stained for 10 min with $3 \%$ Giemsa stain (Merck) diluted in buffer solution, $\mathrm{pH} 6.8$.

The slides were coded and scored in a blind manner using light microscopy. One thousand metaphases per treatment were observed for the analysis of chromosome abnormalities (gaps and breaks). The mitotic index was calculated by counting a total of 3000 cells at each concentration using the formula mitotic index $=$ (number of cells in division/total number of cells) x 100 . The polyploidy index was calculated by counting a total of 1000 cells (regardless of their stage in the cell cycle) at each concentration, using the formula polyploidy index $=$ (number of polyploid cells/total number of cells) x 100 .

Two statistical tests were used for the analysis of chromosome abnormalities: chisquare for the proportion of abnormal cells, and Mann-Whitney U-test for the frequency of gaps and breaks (total number of abnormalities per 100 cells). The Statistica Stat Soft software was used for statistical evaluation. A cell with two or more abnormalities was counted as one for the chi-square test, but as two or more abnormalities for the Mann-Whitney test. The chi-square test was also used to identify the differences in the frequency of polyploidy and mitotic index between treated cultures and controls.

\section{Results and Discussion}

Table 1 shows that the mean mitotic index obtained from the analysis of the 3000 cells/concentration was from 0.12 to $4.0 \%$. The cytotoxic effects of $\mathrm{CH}_{3} \mathrm{HgCl}$ were relatively greater, as demonstrated by a significant dose-related decrease in mitotic index following exposure to this compound alone or in combination with $\mathrm{HgCl}_{2}$. A synergistic cytotoxic effect was observed when cells were exposed simultaneously to both compounds. Such effect was also observed in TK6 cells simultaneously exposed to the same agents (18).

Table 2 summarizes the results of analysis of chromosome aberrations in human peripheral lymphocytes in culture following treatment with different concentrations of mercury compounds and their negative controls. The data obtained from 1000 metaphases analyzed per treatment (100 metaphases/individual) showed a significant increase in the frequency of chromatid gaps and chromosomal alterations for all $\mathrm{CH}_{3} \mathrm{HgCl}$ concentrations. The same effect was ob- 
Table 1. Mean mitotic index (\%) of cells treated with different concentrations of mercury chloride and methylmercury chloride.

\begin{tabular}{lcccccc}
\hline $\begin{array}{l}\text { Concentration } \\
(\mu \mathrm{g} / \mathrm{l})\end{array}$ & $\begin{array}{c}\mathrm{HgCl}_{2} \\
(\mathrm{~A})(\%)\end{array}$ & $\begin{array}{c}\mathrm{CH}_{3} \mathrm{HgCl} \\
(\mathrm{B})(\%)\end{array}$ & $\begin{array}{c}\mathrm{HgCl}_{2}+\mathrm{CH}_{3} \mathrm{HgCl} \\
\text { (C) }(\%)\end{array}$ & $\begin{array}{c}\mathrm{P}) \\
(\mathrm{A} \text { vs B) }\end{array}$ & $\begin{array}{c}\mathrm{P} \text { (A vs C) } \\
\text { (B vs C) }\end{array}$ \\
\hline 0 & $4.09 \pm 0.1729$ & $4.18 \pm 0.2150$ & $4.22 \pm 0.1814$ & $\mathrm{NS}$ & $\mathrm{NS}$ & $\mathrm{NS}$ \\
0.1 & $4.01 \pm 0.1450$ & $3.78 \pm 0.1752$ & $3.43 \pm 0.1889$ & $* *$ & $* *$ & $\mathrm{NS}$ \\
1 & $3.96 \pm 0.1776$ & $3.32 \pm 0.1814$ & $2.66 \pm 0.1265^{*}$ & $\mathrm{NS}$ & $* *$ & $* *$ \\
10 & $3.65 \pm 0.1179$ & $2.85 \pm 0.1581$ & $1.52 \pm 0.1989 *$ & $* *$ & $* *$ & $* *$ \\
100 & $3.17 \pm 0.1338$ & $2.15 \pm 0.2014 *$ & $0.58 \pm 0.3490^{*}$ & $* *$ & $* *$ & $* *$ \\
1000 & $3.00 \pm 0.1247$ & $1.63 \pm 0.1889 *$ & $0.12 \pm 0.1751^{*}$ & $* *$ & $* *$ & $* *$ \\
\hline
\end{tabular}

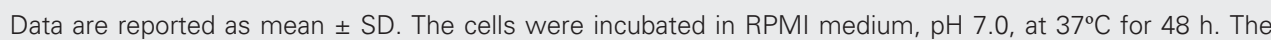
mitotic index was calculated for 3000 cells per concentration. $\mathrm{HgCl}_{2}=$ mercury chloride; $\mathrm{CH}_{3} \mathrm{HgCl}=$ methylmercury chloride.

${ }^{*} \mathrm{P}<0.05$ compared to control (chi-square test); ${ }^{*} \mathrm{P}<0.05$ for data compared between columns (chisquare test). NS = not statistically significant.

Table 2. Relative frequency of cells with gaps, breaks and gaps plus breaks after exposure to mercury chloride and methylmercury chloride.

\begin{tabular}{|c|c|c|c|c|c|c|c|}
\hline \multirow[t]{2}{*}{ Agent } & \multirow{2}{*}{$\begin{array}{c}\text { Concentration } \\
(\mu \mathrm{g} / \mathrm{l})\end{array}$} & \multicolumn{2}{|c|}{ Gaps (\%) } & \multicolumn{2}{|c|}{ Breaks (\%) } & \multicolumn{2}{|c|}{$\begin{array}{c}\text { Cells with } \\
\text { alterations (\%) }\end{array}$} \\
\hline & & Number & $\operatorname{RF}(\%)$ & Number & RF (\%) & Number & $\operatorname{RF}(\%)$ \\
\hline \multirow[t]{6}{*}{$\mathrm{HgCl}_{2}$} & 0 & 6 & 0.6 & 1 & 0.1 & 7 & 0.7 \\
\hline & 0.1 & 12 & $1.2^{*}$ & 2 & 0.2 & 14 & $1.4^{*}$ \\
\hline & 1 & 7 & 0.7 & 0 & 0.0 & 7 & 0.7 \\
\hline & 10 & 9 & 0.9 & 0 & 0.0 & 9 & 0.9 \\
\hline & 100 & 6 & 0.6 & 0 & 0.0 & 6 & 0.6 \\
\hline & 1000 & 11 & $1.1^{*}$ & 2 & 0.2 & 13 & $1.3^{*}$ \\
\hline \multirow[t]{6}{*}{$\mathrm{CH}_{3} \mathrm{HgCl}$} & 0 & 5 & 0.5 & 2 & 0.2 & 7 & 0.7 \\
\hline & 0.1 & 128 & $12.8^{*}$ & 7 & 0.7 & 135 & $13.5^{*}$ \\
\hline & 1 & 119 & $11.9 *$ & 7 & 0.7 & 126 & $12.6^{*}$ \\
\hline & 10 & 70 & $7.0^{*}$ & 2 & 0.2 & 72 & $7.2^{*}$ \\
\hline & 100 & 33 & $3.3^{*}$ & 3 & 0.3 & 36 & $3.6^{*}$ \\
\hline & 1000 & 118 & $11.8^{*}$ & 4 & 0.4 & 122 & $12.2^{*}$ \\
\hline \multirow[t]{6}{*}{$\mathrm{HgCl}_{2}+\mathrm{CH}_{3} \mathrm{HgCl}$} & 0 & 5 & 0.5 & 2 & 0.2 & 7 & 0.7 \\
\hline & 0.1 & 79 & $7.9 *$ & 7 & 0.7 & 86 & $8.6^{*}$ \\
\hline & 1 & 137 & $13.7^{*}$ & 7 & 0.7 & 144 & $14.4^{*}$ \\
\hline & 10 & 200 & $20.0^{*}$ & 2 & 0.2 & 202 & $20.2^{*}$ \\
\hline & 100 & 214 & $21.4^{*}$ & 3 & 0.3 & 217 & $21.7^{*}$ \\
\hline & 1000 & 244 & $24.4^{*}$ & 4 & 0.4 & 248 & $24.8^{*}$ \\
\hline
\end{tabular}

Data are reported for 10 independent experiments. One thousand cells were examined per treatment. The cells were incubated in RPMI medium, $\mathrm{pH} 7.0$, at $37^{\circ} \mathrm{C}$ for $48 \mathrm{~h} . \mathrm{HgCl}_{2}=$ mercury chloride; $\mathrm{CH}_{3} \mathrm{HgCl}=$ methylmercury chloride; $\mathrm{RF}=$ relative frequency.

${ }^{*} \mathrm{P}<0.05$ compared to control. The chi-square test was used for the proportion of cells with alterations and the Mann-Whitney U-test for the relative frequency of gaps and breaks (total number of abnormalities per 100 cells). 
served for the simultaneous treatments, together with a synergistic effect.

The frequency of polyploid aberrations (Table 3) was significantly different between cells treated with $\mathrm{CH}_{3} \mathrm{HgCl}$ and cells treated simultaneously with the two compounds when compared to the respective controls. A dose-dependent increase in the frequency of polyploid cells was observed for these treatments and the lowest levels of polyploid aberrations were observed at the different $\mathrm{HgCl}_{2}$ concentrations.

Mercury compounds induce a general collapse of antioxidant mechanisms in the cell by binding to the sulfhydryl groups of glutathione, a radical scavenger. Such a collapse results in cell degeneration, loss of membrane integrity and finally cell necrosis (6). Necrosis can be indicated by a decrease in mitotic index, as shown by the present results. A decrease in mitotic index followed by an increase in the generation of reactive oxygen species was detected in human blood lymphocytes exposed to $\mathrm{CH}_{3} \mathrm{HgCl}$ (15).

Another mechanism that may contribute to cell death induced by mercury compounds is apoptosis. Shenker et al. (19) reported that $\mathrm{CH}_{3} \mathrm{HgCl}$ caused a significant increase in cytochrome $c$ in the cytosol of $\mathrm{T}$ cells. In contrast, $\mathrm{HgCl}_{2}$ did not alter the levels of cytosolic cytochrome $c$, suggesting that the apoptotic pathway triggered by $\mathrm{HgCl}_{2}$ compounds is independent of cytochrome $c$ release. This effect may justify the higher cytotoxic action of $\mathrm{CH}_{3} \mathrm{HgCl}$, as observed in the present study. Previous results obtained by our group for TK6 cells support the higher cytotoxic effect of $\mathrm{CH}_{3} \mathrm{HgCl}$ compared to $\mathrm{HgCl}_{2}$ (18). A higher cytotoxic effect of $\mathrm{CH}_{3} \mathrm{HgCl}$ compared to $\mathrm{HgCl}_{2}$ was also found by other authors (15) after exposure of human lymphocytes to these compounds.

A number of in vitro studies on the genotoxic effects of mercury and its compounds based on cytogenetic tests have been published. Their results suggest that organic compounds are generally more active, in terms of genotoxicity, than inorganic compounds $(5,15,18,20)$. The binding of this metal to sulfhydryl groups of glutathione blocks its function as a free radical scavenger (19). Thus, free radicals become available to cause DNA damage (15). These mechanisms can lead to "double-strand breaks" that can be visualized as the chromatid gaps observed in the present study (21) and/or give rise to more evident chromosome alterations such as breaks, rearrangements, and so on (22).

In the present study, a significant dose-

\begin{tabular}{|c|c|c|c|c|c|c|}
\hline $\begin{array}{l}\text { Concentration } \\
(\mu \mathrm{g} / \mathrm{l})\end{array}$ & $\begin{array}{l}\mathrm{HgCl}_{2} \\
\text { (A) }(\%)\end{array}$ & $\begin{array}{l}\mathrm{CH}_{3} \mathrm{HgCl} \\
\text { (B) }(\%)\end{array}$ & $\begin{array}{c}\mathrm{HgCl}_{2}+\mathrm{CH}_{3} \mathrm{HgCl} \\
\text { (C) }(\%)\end{array}$ & $\begin{array}{c}\mathrm{P} \\
(\mathrm{A} \vee s \mathrm{~B})\end{array}$ & $\begin{array}{c}P \\
(A v s \text { C) }\end{array}$ & $\begin{array}{c}\mathrm{P} \\
(\mathrm{B} v s \mathrm{C})\end{array}$ \\
\hline 0 & $0.4 \pm 0.0227$ & $0.6 \pm 0.6921$ & $0.6 \pm 0.3268$ & NS & NS & NS \\
\hline 0.1 & $0.3 \pm 0.0325$ & $13.0 \pm 1.3546^{*}$ & $13.0 \pm 1.2364^{*}$ & $* *$ & $* *$ & NS \\
\hline 1 & $0.2 \pm 0.0926$ & $22.2 \pm 1.2351^{*}$ & $22.5 \pm 1.6329^{*}$ & $* *$ & $* *$ & NS \\
\hline 10 & $0.3 \pm 0.0086$ & $24.9 \pm 3.1993^{*}$ & $25.6 \pm 1.3665^{*}$ & $* *$ & $* *$ & NS \\
\hline 100 & $0.5 \pm 0.0634$ & $46.6 \pm 3.5369^{*}$ & $46.0 \pm 2.3625^{*}$ & $* *$ & $* *$ & NS \\
\hline 1000 & $0.5 \pm 0.1436$ & $64.3 \pm 1.8961 *$ & $67.2 \pm 5.2438^{*}$ & $* *$ & $* *$ & NS \\
\hline
\end{tabular}


related increase in the number of cells showing chromosome aberrations was observed after treatment with $\mathrm{CH}_{3} \mathrm{HgCl}$ (Table 2). However, such increase was not linearly related to dose. This effect can be explained by the fact that $\mathrm{CH}_{3} \mathrm{HgCl}$ acts similarly to $\mathrm{X}$ rays (23), increasing DNA damage in a dosedependent manner until a plateau is reached, with a decrease in damage being observed even though the doses continue to increase. This effect reflects two different phenomena: a dose-dependent increase in the proportion of normal cells whose DNA is damaged and a dose-dependent decrease of the probability that such cells can survive higher exposures (24). Similar results were observed on TK6 cells after exposition to $\mathrm{CH}_{3} \mathrm{HgCl}(18)$.

The increased incidence of polyploidy observed in the present study confirms a characteristic effect of mercury compounds, i.e., their action on the mitotic spindle. The strong affinity of mercury for sulfhydryl groups available in the spindle impairs the function of the latter, leading to mistakes in chromosome segregation during cell division and consequently to polyploidy or aneuploidy $(5,8,18)$. These events can be involved in spontaneous abortion, birth defects, cell transformation, and the process of tumor progression (25).

In the present study, we used a range of mercury doses $(0.1$ to $1000 \mu \mathrm{g} / 1, \mathrm{ppb})$ considered to be low. Much higher concentrations are found in people who live in contami- nated areas $(2,26)$. Our results showed that exposure of peripheral blood lymphocytes to low doses of $\mathrm{CH}_{3} \mathrm{HgCl}$ is sufficient for the expression of evident genotoxic and cytotoxic effects. However, caution should be taken in using the present results to estimate the risks for populations exposed to low doses of mercury since the appropriate assessment of the genotoxic potential of an agent requires the use of different assays that will permit the evaluation of different genetic events in different cell types (27).

Despite the existence of constraints in the extrapolation of in vitro to in vivo data in humans, the cytotoxicity of mercury compounds requires special attention in view of the major damage it causes in cell function, resulting in the inability of cells to proliferate. These disturbances frequently appear long before the manifestation of genotoxic effects, or even in the absence of the latter. Thus, the cytotoxic effect may be considered an earlier indication of cellular damage with possible biological consequences and should be taken into account in the preliminary evaluation of the risks to populations exposed in vivo, as already suggested by others $(8,18)$.

\section{Acknowledgments}

The authors thank Prof. Ene Glória da Silveira, Departamento de Geografia, Universidade Federal de Rondônia, for support during this study.

\section{References}

1. Aleo MF, Morandini F, Benttoni F et al. (2002). In vitro study of the nephrotoxic mechanism of mercuric chloride. Medicina del Lavoro, 93: $267-278$

2. Tchounwou PB, Ayensu WK, Ninashvili N \& Sutton D (2003). Environmental exposure to mercury and its toxicopathologic implications for public health. Environmental Toxicology, 18: 149-175.

3. Faustman EM, Ponce RA, Ou YC, Mendonza MA, Lewandowski R \& Kavanagh $T$ (2002). Investigations of methylmercury-induced alterations in neurogenesis. Environmental Health Perspectives,
110: 859-864.

4. Clarkson RW (2002). The three modern faces of mercury. Environmental Health Perspectives, 110: 11-23.

5. De Flora S, Benniceli C \& Bagnasco M (1994). Genotoxicity of mercury compounds. A review. Mutation Research, 317: 57-79.

6. Schurz F, Sabater-Vilar M \& Fink-Gremmels J (2000). Mutagenicity of mercury chloride and mechanisms of cellular defence: the role of metal-binding proteins. Mutagenesis, 15: 525-530.

7. Ehrenstein C, Shu P, Wickenheiser EB, Hirner AV, Dolfen M, 
Emons H \& Obe G (2002). Methyl mercury uptake and associations with the induction of chromosomal aberrations in Chinese hamster (CHO) cells. Chemico-Biological Interactions, 141: 259-274.

8. Amorim MIM, Mergler D, Bahia MO, Dubeau H, Miranda D, Lebel J, Burbano RR \& Lucotte M (2000). Cytogenetic damage related to low levels of methyl mercury contamination in the Brazilian Amazon. Anais da Acadêmia Brasileira de Ciências, 72: 497-507.

9. Franchi E, Loprieno G, Ballardin M, Petrozzi L \& Migliore L (1994). Cytogenetic monitoring of fishermen with environmental mercury exposure. Mutation Research, 320: 23-29.

10. Al-Sabti K, Lloyd DC, Edwards AA \& Stenar P (1992). Survey of lymphocyte chromosomal damage in Slovenian workers exposed to occupational clastogens. Mutation Research, 280: 215-223.

11. Anwar WA \& Gabal MS (1991). Cytogenetic study in workers occupationally exposed to mercury fulminate. Mutagenesis, 6: 189-192.

12. Hansteen H, Ellingsen DG, Clausen KO \& Kjuus H (1993). Chromosome aberrations in chloralkali workers previously exposed to mercury vapour. Scandinavian Journal of Work, Environment and Health, 19: 375-381.

13. Mabille V, Roels $H$, Jacquet $P$, Léonard A \& Lauweris $R$ (1984). Cytogenetic examination of leucocytes of workers exposed to mercury vapour. International Archives of Occupational and Environmental Health, 53: 257-260.

14. Committee on the Toxicological Effects of Methylmercury, Board on Environmental Studies and Toxicology and National Research Council (2000). Toxicological Effects of Methylmercury. The National Academies Press, Washington, DC, USA.

15. Ogura H, Takeuchi T \& Morimoto K (1996). A comparison of the 8hydroxydeoxyguanosine, chromosome aberrations and micronucleus techniques for the assessment of the genotoxicity of mercury compounds in human blood lymphocytes. Mutation Research, 340: 175-182.

16. Betti C, Barale R \& Pool-Zobel BL (1993). Comparative studies on cytotoxic and genotoxic effects of two organic mercury compounds in lymphocytes and gastric mucosa cells of Sprague-
Dawley rats. Environmental and Molecular Mutagenesis, 22: 172 180.

17. Betti C, Davini T \& Barale R (1992). Genotoxic activity of methyl mercury chloride and dimethyl mercury in human lymphocytes. Mutation Research, 281: 255-260.

18. Bahia MO, Amorim MIM, Burbano RR, Vincent $S$ \& Dubeau $H$ (1999). Genotoxic effects of mercury on in vitro cultures of human cells. Anais da Academia Brasileira de Ciências, 71: 437-443.

19. Shenker BJ, Guo TL \& Shapiro IM (2000). Mercury-induced apoptosis in human lymphoid cells: evidence that the apoptotic pathway is mercurial species dependent. Environmental Research. Section A, 84: 89-99.

20. Gebhart E \& Rossman TG (1991). Mutagenicity, carcinogenicity and teratogenicity. In: Merian E (Editor), Metals and Their Compounds in the Environment. VCH, New York, 617-640.

21. Harvey AN, Costa ND, Savage JR \& Thacker J (1997). Chromosomal aberrations induced by defined DNA double-strand breaks: the origin of achromatic lesions. Somatic Cell and Molecular Genetics, 23: $211-219$

22. Morgan WF, Corcoran J, Hartmann A, Kaplan MI, Limoli CL \& Ponnaiya B (1998). DNA double-strand breaks, chromosomal rearrangements, and genomic instability. Mutation Research, 404: 125-128.

23. Betti C, Davini T, He J \& Barale R (1993). Liquid holding effects on methylmercury genotoxicity in human lymphocytes. Mutation Research, 301: 267-273.

24. Hall EJ (2000). Radiobiology for the Radiologist. 5th edn. Lippincott Williams \& Wilkins, Philadelphia, PA, USA.

25. Kirsch-Volders M, Vanhauwaert A, De Boeck M \& Decordier I (2002). Importance of detecting numerical versus structural chromosome aberrations. Mutation Research, 504: 137-148.

26. Gochfeld M (2003). Cases of mercury exposure, bioavailability and absorption. Ecotoxicology and Environmental Safety, 56: 174-179.

27. Bahia MO (1997). Le potentiel génotoxique du mercure: mutations HPRT' et effets cytogénetiques. Master's thesis, Université du Québec à Montréal, Montréal, Canada. 